\title{
PREVENTION OF MALARIA IN INDIA
}

\author{
RECENT ADVANCES \\ By Sir Malcolm Watson, \\ Director, Ross Institute of Tropical Hygiene
}

$\mathrm{A}^{\mathrm{I}}$ LTHOUGH the primary object of my recent visit to India was to see what progress had been made in preventing malaria on estates advised by the India Branch of the Ross Institute, I took the opportunity of visiting Delhi and Hyderabad, Deccan. In all these areas astonishing progress has been made since my visit in 1928-1929.

For more than a thousand years there has been a succession of cities on the western bank of the River Jumna within six miles of new Imperial Delhi. Some of the cities were far enough from the river to escape the malarial mosquitoes which breed in pools in its bed. But three hundred years ago Shah Jehan made the mistake of building his city right on the river bank; the Western Jumna Canal irrigated its northern area; the Darhalia Nala flowed through the western suburb. In all three, Anopheles culicifacies bred in profusion; and at times Shahjehanabad was the most malarial military station in India. In 1903 the General Officer commanding the Division commented on "the havoc caused in the Delhi Fort garrison". Of the relieved force, 315 per 1,000 were unable to march back to Meerut, and of the remainder quite one fourth were scarcely fit to carry arms. A few years later the cantonment of Daryaganj in the south-east corner of the Fort and immediately on the Jumna was abandoned on account of malaria. New Delhi, built not quite so near to the river as its immediate predecessor, provided accommodation for myriads of $A$. culicifacies in the four hundred miles of margins of concrete tanks which adorn the new capital. Further accommodation for the anopheles was provided in pits in two hundred acres of brickfields and in innumerable artificial obstructions to natural drainage channels.

To-day a five years programme for the control of malaria is well advanced. It covers the eight miles of river bank and the various streams and canals falling into the river, the irrigated area, the brickfields and much besides: good sound work that is producing the required result. Indeed, Daryaganj, the abandoned, is now being developed as a residential area.

Not less interesting, and of great importance to India, is the control of malaria in sixty-six villages within three miles of the city, and in sixty villages farther afield. The work is being done after careful study of the habits of the dangerous anopheles, A. culicifacies. Depressions have been filled, and the land sloped to run all surface water to one or more of the village tanks, where any mosquitoes that breed can easily be destroyed. While concentrating on the prevention of malaria, water supplies have been improved, and the general cleanliness of the villages has not been neglected. The co-operation of the villagers has been seeured. The anti-malarial work at Delhi is under Lieut.Colonel Covell, director of the Malaria Institute of India. It costs money-often much moneyto repair mistakes that could have been avoided in the original work without additional expense. Now co-operation between the various authorities prevents more man-made malaria, and $\mathrm{I}$ was impressed by the economy and efficiency of the work.

The prevention of malaria by the Government of India has not been confined to Delhi Province. The Government of H.E.H. the Nizam has reduced the percentage of children suffering from malaria in the old eity of Hyderabad (one of the worst areas) from 55 to 0.5 ; a suburb of the city, falling into decay in 1929, is now thriving and land values have risen; a completely new suburb has been built on land previously regarded as uninhabitable. Twenty years ago there were 16,000 deaths a year from plague, now there are. 100 or less. Slum clearance proceeds rapidly, and there are many attractive rehousing schemes. Some of the small houses, the economic rent of which would be Rs. 3 a month, are let at Rs. 1 a month to those who abjure alcohol. These houses have pillars shaped like inverted tumblers -a reminder of the pledge. Improvements in many other ways have been made, and with its progressive Government Hyderabad is becoming a model Indian city; nor have the improvements been confined to the capital of the State.

For more than two months I toured estates in southern India; the Surma and Assam valleys; and the Dooars, an area under the shadow of the Himalayas. In many of these districts malaria had been intense and blackwater a too frequent visitant. Since I made much the same tour eleven years ago a great change has occurred. Almost 
everywhere on the estates the prevention of malaria is in active progress. Confidence has replaced pessimism; on many estates managers, assistants and medical officers are full of enthusiasm at the wonderful results achieved. Although I made constant inquiry I heard of no case of blackwater fever in a European in the last two year's.

Sixteen years ago, when I spent three months in Assam on the invitation of the directors of the Doom. Dooma and its associated companies, the control of malaria by controlling mosquitoes was regarded as impossible. The Assam Valley, or syncline between the Himalayas and the Burma Hills, three hundred miles long and fifty miles wide, is, I am told, filled with detritus from the hills to a depth of three miles. To the eye it appears a level plain, and it well might as it was formerly an arm of the sea; even now the Brahmaputra River is navigable almost the whole length of the valley throughout the year. In the spring the melting snows of the Himalayas and vast areas of Tibet make it one of the mighty rivers of the world, five to seven miles wide. Its waters flood back into the local rivers, mere tributaries of the Brahmaputra, but some wider than the Thames at Westminster. Then with scarcely an interval come the monsoon rains-80-120 inches in less than six months. Hundreds of square miles disappear under water; for wherever possible water is stored by the Assamese, whose staple food, rice, is grown in sheets of standing water. Can we wonder that more than twenty species of anopheles have found the valley a happy home, or that to the earlier investigators the malarial problem of controlling mosquitoes seemed insoluble?

My researches in Assam, and more than twenty years experience of Malaya, led me to take another view. Between 1900 and 1910 the combination of research and practical work in Malaya showed the openings in the mosquitoes' armour. The work had included, in addition to laboratory work, largescale experiments in which miles and years took the place of millimetres and minutes; for the malaria problem could not, in the end, be brought within the four walls of any laboratory. We had learned that, although there were many species of anopheles all of which could be artificially infected in a laboratory, few became infected when wild, and happily few areas had more than one dangerous species; that to control malaria we had to control only the dangerous species; that the larvæ of the different species lived under different conditions of light and shade, of stagnation or movement of water ; that changes in these conditions or in the chemical composition of the water would change the species present; and that a method of control 100 per cent successful against one species might be worse than a failure against another species. For example, A. maculatus, the larvæ of which live in hill streams, sparkling in the sunshine, required very different measures of control from A. umbrosus, an inhabitant of junglecovered stagnant swamps. So came about what is known to-day as 'species sanitation'; and in 1910, at a public lecture, I stated that following the methods of limiting and changing species shown to us by Nature, "a great anti-malarial method will be evolved .. . we shall be able to play with species of anophelines, say to some 'go' and to others 'come', and abolish malaria with great ease, perhaps at hardly any expense. Drainage may become a method of the past. . . ." In addition to other methods of malaria control like site selection and oiling, Nature's methods are widely employed on estates in India to-day.

Dr. G. C. Ramsay followed up my researches in India. He proved $A$. minimus to be the only important carrier of malaria on the estates in his practice, and went on to control it. In 1930 he was appointed head of the India Branch of the Ross Institute. His scheme of training young Indians has been expanded by Dr. Manson, Dr. Fraser and other medical officers co-operating with the Ross Institute, and to-day more than five hundred trained Indians are employed on estates to identify the species of anopheles caught, to dissect them to see if they are infected with malaria, to collect anopheles larvæ and prepare maps showing the breeding places of the different species. Small field research stations have been temporarily opened in different parts of India from Cape Comorin to the Himalayas, from Sind to Assam. More than two hundred thousand anopheles have been dissected and several species have been convicted of carrying malaria. There are now one or two permanent training centres to meet the demand for trained malarial surveyors -a new and useful form of employment for the educated Indian fresh from school.

To control the different species of anopheles appropriate methods are employed. A description of some of them would be strange reading for those who were taught only of the danger of jungle, of stagnant water, and swamps, and have not been initiated into the secrets and mysteries of modern malaria control.

For example, on many estates in India, as in Delhi, much malaria has been 'man-made'. Over wide areas of both northern and southern India, the malaria is entirely due to man interfering with Nature by his clearing away jungle from streams and exposing them to the sunshine, and by his draining swamps. For by doing so he has driven out the jungle-loving or harmless species and 
permitted the breeding of dangerous species- $A$. minimus in the north, $A$. fuviatilis or A. culcifacies at different elevations in the south. Intermittent flushing will wreck the home of even the fastest stream-breeding malaria-carrier in the world; it is much used in India. Streams are flushed by hand-operated openings in simple shilling or less, of a design that would rejoice the heart of Mr. Heath Robinson ; or by more elaborate things of concrete and iron. In other places, if man holds his hand, Nature will cover up her wounds with secondary jungle, but often she is too slow and we must replant appropriate shade. So we see the strange sight of hundreds of acres of little squares of almost stagnant water growing rice in the sunshine, and down the centre of the

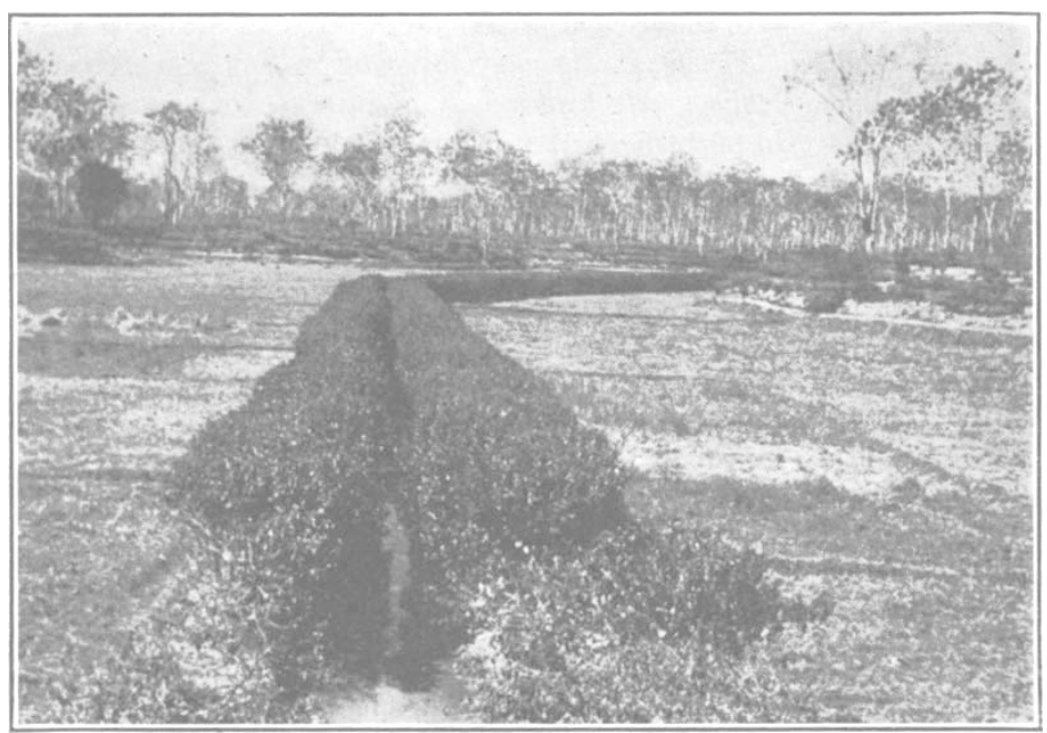

ANTi-malarial hedGe iN a Rice field (PRUNed in NON-Matartal SEASON). earth dams; by automatic tippers, costing a

From a commercial point of view, a remark made by the head of one of the largest tea-producing concerns in India represents the general opinion: "We have gone carefully into the figures and are convinced of the value of malaria control"; and he added, "in fact we have some of the finest examples of the control of malaria both in north and south India", for the truth of which remark I can vouch. The following are figures from one group of estates, representative of many:

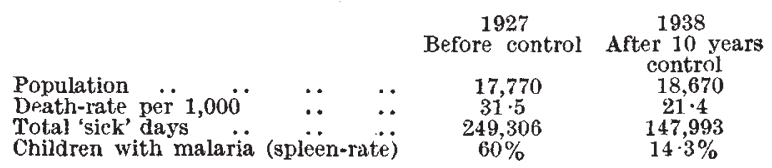

To the employer these figures mean a lower sickrate, a lower death-rate, greater efficiency in his labour force and lower cost of production. To the labourer they mean healthier and happier homes and a higher pay packet at the end of the month : 100,000 more days pay than ten years ago, on this particular group of estates. Until the new standardized returns come into general use, we shall not be able to compute the total benefit to the Indian labourer on estates; even now we can think, without the least fear of exaggeration, in terms of a gain of more than a million days wages a year.

This work has not been confined to the European-owned estates. Already several Indianowned and Indian-managed estates have joined the local Ross rice fields a stream densely shaded by a hedge; it may be of the lovely shoe flower (Hibiscus), the wild rhododendron (Melastoma), the notorious Lantana or other plants. The centre stream alone was the danger. The hedge bas made it harmless, and an intense source of malaria has been eliminated. The accompanying photograph shows a rice field in the dry weather with the hedge pruned to make the shade denser in the rainy malarial season. There are 2,000 miles of these dense hedges now, and 4,000 miles will be effective by the end of the year.

Progress has not been confined to the prevention of malaria. I was astonished to see the general improvement in the water supplies, in latrine accommodation, in refuse collection and disposal, in housing of the labourers, in the hospital buildings and the high standard of medical work in so many of them, the care of the sick and the ante-natal work.
Institute centres, and the Governments of Assam and Madras are co-operating with the estates to improve the health of several villages. The hope has been expressed that the European estates with their trained staffs will assist their Indian neighbours to control malaria and other diseases, to the advantage of both and the removal of what is at present a source of friction.

On Dr. G. C. Ramsay, deputy director of the Ross Institute, has fallen the heat and burden of the day. He. has succeeded only because of the fine co-operation of his medical colleagues and the planters and of the support of the directors in India and at home. Sometimes the question is asked: "Can any good [medical] thing come out of Britain"? So perhaps I may be excused for expressing the opinion that the work in India is the greatest achievement in the control of malaria in the past decade; that the best of it, and there is much 'best', is worthy of comparison with the 
best work done at Panama or with Mussolini's great achievement in the Pontine Marshes ; and in area it is vastly greater than either. Moreover, both could learn something to their advantage from India. Nor is this the whole story; for Ceylon, certain areas in British Africa, and Malaya have also fine records in preventing malaria-in Malaya begun even before Panama.

This story would not be complete without mention of how this work was made possible. The late Sir Charles McLeod, first chairman of the Ross Institute, who used to insist that "malaria, malaria, malaria" was the great enemy, and a number of his friends in the City financed the India Branch of the Ross Institute during 19301933, when the responsibility was taken over by the Indian Tea Association.

During this tour I visited the humble laboratory at Hyderabad in which Ronald Ross made his immortal discovery. Often I wished he could have been with me to see how mosquito reduction had spread still farther into rural areas, which as he wrote to me in 1909 he had "never dared to moot".

\title{
THE CORROSION OF FERROUS METALS
}

\author{
By Dr. J. Newton Friend, \\ Central Technical College, Birmingham
}

$\mathrm{I}^{\mathrm{N}}$ 1916 a committee was formed by the Institution of Civil Engineers, under the chairmanship of the late Sir William Matthews, to investigate the "Deterioration of Structures exposed to Sea Action". The Department of Scientific and Industrial Research gave every encouragement and offered substantial financial assistance.

An important section of the work undertaken by the Committee is that dealing with the corrosion of iron and steel. This research has now been completed. Series of bars of fourteen different kinds of ferrous metal, measuring 2 feet in length, 3 inches in width and 0.5 inch in thickness, were exposed at various ports to sea air, to alternate sea air and wetting with sea water or spray, and to continuous immersion in the sea. Three sets were exposed at each port to each of these conditions, one for five years, one for ten and the third for fifteen years. The results obtained with the five and ten year bars have already been fully discussed in the Committee's Fifteenth Report (1935). As yet only the numerical data for the fifteen-year bars have been made public in the Committee's Seventh Interim Report (1938), the full report being temporarily held up on account of the War. It may be said at once that these last results support the earlier ones very satisfactorily, and it is the purpose of this article to mention a few of the more important practical conclusions to be derived from the numerous data now published.

The ports chosen for the exposure of the bars were Auckland (New Zealand), Halifax (Canada), Plymouth (England), and Colombo (Ceylon). These were selected as offering a wide variation in climatic conditions. Thus Colombo has a moist, tropical climate, and the total loss in weight suffered by the bars through corrosion at this port was twice that experienced at Plymouth, three times that at Halifax and nearly four times that at Auckland. Nevertheless, the relative losses among comparable sets of bars were quite analogous and thus enable us to draw many useful conclusions with a high degree of confidence.

The severe nature of the corrosion at Colombo is illustrated in Fig. 1. The steel bar B14 was perforated near its middle after exposure at halftide level for ten years, whilst, after fifteen years exposure under similar conditions, bar $E 15$, also of mild steel, was completely eaten in two.

At Plymouth three sets of bars were exposed to fresh-water action by immersion in the reservoir at Turnchapel for the above-mentioned periods.

In all cases the bars were maintained in a vertical position by embedding their ends in concrete, which was carefully punned into position so that no air holes or porous sections were left around the metals. The concrete proved an ideal material for the purpose. After fifteen years exposure the metal beneath the concrete was in perfect condition, except in a few cases where the concrete had cracked from one cause or another.

Moist concrete is not a perfect insulator, particularly when impregnated with salt water. Experiments carried out at Plymouth showed that minute electric currents undoubtedly passed through the frames when immersed in the sea. Hence a small amount of electrolytic corrosion was induced in some of the specimens. Most fortunately, measurement showed that this was too small to affect seriously the results, owing to the relatively great distance between the 